\title{
Alteration in the temporal organisation of insulin secretion in Type 2 (non-insulin-dependent) diabetic patients under continuous enteral nutrition
}

\author{
C.Simon ${ }^{1}$, G. Brandenberger ${ }^{1}$, M. Follenius ${ }^{1}$ and J. L. Schlienger ${ }^{2}$ \\ ${ }^{1}$ Laboratoire de Physiologie et de Psychologie Environnementales, CNRS/INRS, and \\ ${ }^{2}$ Service de Médecine Interne, CHU Hautepierre, Strasbourg, France
}

\begin{abstract}
Summary. Concomitant oscillations of plasma glucose, insulin and C-peptide levels with a period of about $80 \mathrm{~min}$ between peak levels have been identified in normal man. To determine whether these oscillations persist in Type 2 (noninsulin-dependent) diabetic patients, peripheral plasma levels of glucose, insulin and C-peptide were measured at $10 \mathrm{~min}$ intervals over $12 \mathrm{~h}$ in six patients and in six matched control subjects during continuous enteral nutrition ( $90 \mathrm{kcal}^{-\mathrm{h}^{-1}} ; 50 \%$ carbohydrate, $35 \%$ fat, $15 \%$ protein). The insulin secretion rate was estimated from peripheral C-peptide levels using an open two-compartment model. For the control subjects, mean plasma glucose, insulin and insulin secretion profiles rose sharply and then attained a steady-state; in contrast, for the diabetic patients, the mean insulin and insulin secretion profiles were characterized by a slow ascending trend throughout the day. Mean glucose levels rose sharply and reached higher levels than in the control subjects.
\end{abstract}

The individual $12 \mathrm{~h}$ profiles revealed synchronous oscillations of plasma glucose, plasma insulin, and insulin secretion in the control subjects. In the diabetic patients, the number of plasma insulin and insulin secretion pulses was significantly lower; they had a smaller amplitude and were less frequently associated with the glucose pulses. However, plasma glucose levels had a similar oscillatory pattern in the diabetic patients compared with the control subjects, albeit with a higher absolute amplitude. The poor association between glucose and insulin secretion pulses in the diabetic patients suggests that insulin pulses are insufficient to account for the glucose pulses. Slowness in the dynamics of insulin secretion may explain the large initial rise in glucose in the diabetic patients under continuous enteral nutrition.

Key words: Glucose, insulin, C-peptide, diabetic, ultradian rhythm, enteral nutrition.
Fluctuations in peripheral glucose and insulin secretion with a periodicity of about $80 \mathrm{~min}$ have been identified in man and in animals. These oscillations on which the previously described 8-15 min oscillations [1-4] are superimposed are best seen after meal ingestion [5, 6], during continuous enteral nutrition [7], during parenteral infusion [8] or in obese subjects [6], all these situations are characterized by high insulin levels.

The origin of these oscillations remains controversial. The high concomitancy between the insulin and glucose pulses observed in normal subjects suggests that they may reflect an intrinsic property of the insulin-glucose regulatory loop, although the mechanisms controlling the synchronization remain unknown.

Recently, abnormalities of the temporal organisation of insulin pulsatile secretion were found in Type 2 (non-insulin-dependent) diabetes mellitus [9]; however repeated food intake during these experiments did not allow the post-prandial oscillations to be observed for a sufficient length of time. This study was thus performed to determine whether the oscillations in plasma glucose and insulin secretion, as estimated from peripheral C-peptide levels using an open two-compartment mathematical model, persist in the diabetic patients during continuous enteral nutrition which prevents the acute effects of meals. Concomitancy of the changes in peripheral glucose levels and the pulses of insulin secretion rate was also examined.

\section{Subjects and methods}

\section{Subjects}

Six Type 2 diabetic patients aged 36-50 years and six normal men, matched for age and body weight, were studied after an overnight fast. All subjects were within $15 \%$ of desirable body weight based on the Metropolitan Life Insurance Table, 1959. Clinical characteristics of the subjects are provided in Table 1 . The patients, who were receiving oral hypoglycaemic agents associated with dietary therapy to achieve metabolic control, had a mean duration of diabetes of $6.0 \pm 2.9$ years; all had moderately elevated levels of glycosylated haemoglobin (mean \pm SEM: $9.5 \pm 1.4 \%$; upper limit of normal= 
Table 1. Characteristics of the control subjects and diabetic patients

\begin{tabular}{lcc}
\hline & $\begin{array}{l}\text { Control } \\
\text { subjects }\end{array}$ & $\begin{array}{l}\text { Diabetic } \\
\text { patients }\end{array}$ \\
\hline Age (years) & $43.3 \pm 2.2$ & $42.7 \pm 3.2$ \\
Body weight $(\mathrm{kg})$ & $73.5 \pm 2.3$ & $68.7 \pm 3.6$ \\
Body mass index $\left(\mathrm{kg} / \mathrm{m}^{2}\right)$ & $25.1 \pm 0.8$ & $22.8 \pm 0.7$ \\
Glycosylated haemoglobin (\%) & - & $9.5 \pm 1.4$ \\
Mean duration of diabetes (years) & - & $6.0 \pm 2.9$ \\
\hline
\end{tabular}

$6 \%$ ). Therapy was discontinued $24 \mathrm{~h}$ before the start of the study. Informed consent was obtained from all the subjects and the protocol was approved by the Strasbourg Hospital Ethics Committee.

\section{Procedure}

The subjects were studied after an overnight fast, in a supine position. Throughout the study, they received continuous enteral nutrition (Nutrodrip, Wander S.A., Switzerland, 90 kcal.h ${ }^{-1} ; 50 \%$ carbohydrate, $35 \%$ fat, $15 \%$ protein) from 08.00 to 20.00 hours. Two hours before blood sampling began, a catheter was inserted under local anaesthesia into an antecubital vein and kept patent with heparinized $0.9 \% \mathrm{NaCl}$ solution; a nasogastric tube was then inserted and continuous enteral nutrition began at 08.00 hours. Blood samples pooled over $10 \mathrm{~min}$ were collected continuously using a peristaltic pump from 07.30 to 20.00 hours for the measurements of glucose, insulin and $\mathrm{C}$-peptide levels.

\section{Plasma sample measurements}

Blood samples were immediately centrifuged at $4^{\circ} \mathrm{C}$ and plasma was stored at $-20^{\circ} \mathrm{C}$ until assayed. Plasma glucose levels were measured in duplicate with a glucose oxidase method (Boehringer, Mannheim, FRG). The intraassay coefficient of variation (CV) of the assay was $1.3 \%$. Plasma insulin levels were measured in duplicate by the double antibody radioimmunoassay (RIA) of Hales and Randle [10]. The intraassay $\mathrm{CV}$ was $6.6 \%$ for values below $350 \mathrm{pmol} / 1$ and $10.6 \%$ for values between $350 \mathrm{pmol} / \mathrm{l}$ and $700 \mathrm{pmol} / \mathrm{l}$. The sensitivity of the assay was $15 \mathrm{pmol} / 1$. Plasma C-peptide levels were determined in duplicate by RIA (InternationalCIS, Division France, Gif-sur-Yvette, France). The intraassay $\mathrm{CV}$ was $12.0 \%$ for values below $265 \mathrm{pmol} / 1,7.1 \%$ for values between 265 and $850 \mathrm{pmol} / \mathrm{l}$ and $5.5 \%$ for values between 850 and $4000 \mathrm{pmol} / \mathrm{l}$. The sensitivity of the assay was $50 \mathrm{pmol} / \mathrm{l}$. All samples from one individual were analysed in a single assay.

\section{Data analysis}

Insulin secretion rate (ISR). For each subject, the insulin secretion rate during each 10 min interval was derived from the profile of plasma C-peptide levels, using a two-compartment model as proposed by Eaton [11]. This deconvolution method is based on the fact that insulin and C-peptide are co-secreted in equimolar concentrations, and that $C$-peptide, which is not extracted by the liver, has a constant metabolic rate even under non-steady-state conditions [12]. Since the kinetic parameters for C-peptide distribution and metabolism have been found to be very similar in diabetic and non-diabetic subjects [13], the mean constants found by the same authors in the normal subjects were used in our study [8].

Pulse analysis of plasma profiles of glucose, insulin and ISR. The individual $12 \mathrm{~h}$ profiles of glucose, insulin and ISR were analysed using the computer program ULTRA $[14,15]$. This algorithm eliminates all peaks for which either the increment or the decrement does not reach a certain threshold. The threshold for pulse detection was set at two times the CV for glucose and insulin. Peaks of ISR were considered as significant if both the increment and the decrement were greater than four times the upper limit of the CV for C-peptide assay. For each significant pulse, the time of occurrence, the increment, the decrement and the total duration were determined. Paired glucose and insulin
(ISR) profiles were submitted to a pulse analysis of temporal association between glucose and insulin (ISR). Pulses of insulin and ISR were considered to be concomitant with pulses of glucose if their peaks occurred within $20 \mathrm{~min}$ of each other. This time was chosen, since the maximum cross-correlation between glucose and insulin (ISR) values were found for all the subjects and the diabetic patients at time lags between $-20 \mathrm{~min}$ and $+20 \mathrm{~min}$, indicating that the glucose and insulin (ISR) variations are nearly in phase.

\section{Statistical analysis}

The results are expressed as means \pm SEM. Group mean data were compared using the Wilcoxon signed-ranks test for paired data. The significance of difference was evaluated at the $5 \%$ level.

\section{Results}

Mean glucose, insulin and ISR profiles

Figure 1 shows the mean plasma glucose, insulin and ISR profiles in the control subjects and the diabetic patients during the enteral nutrition. As expected, the initial plas-
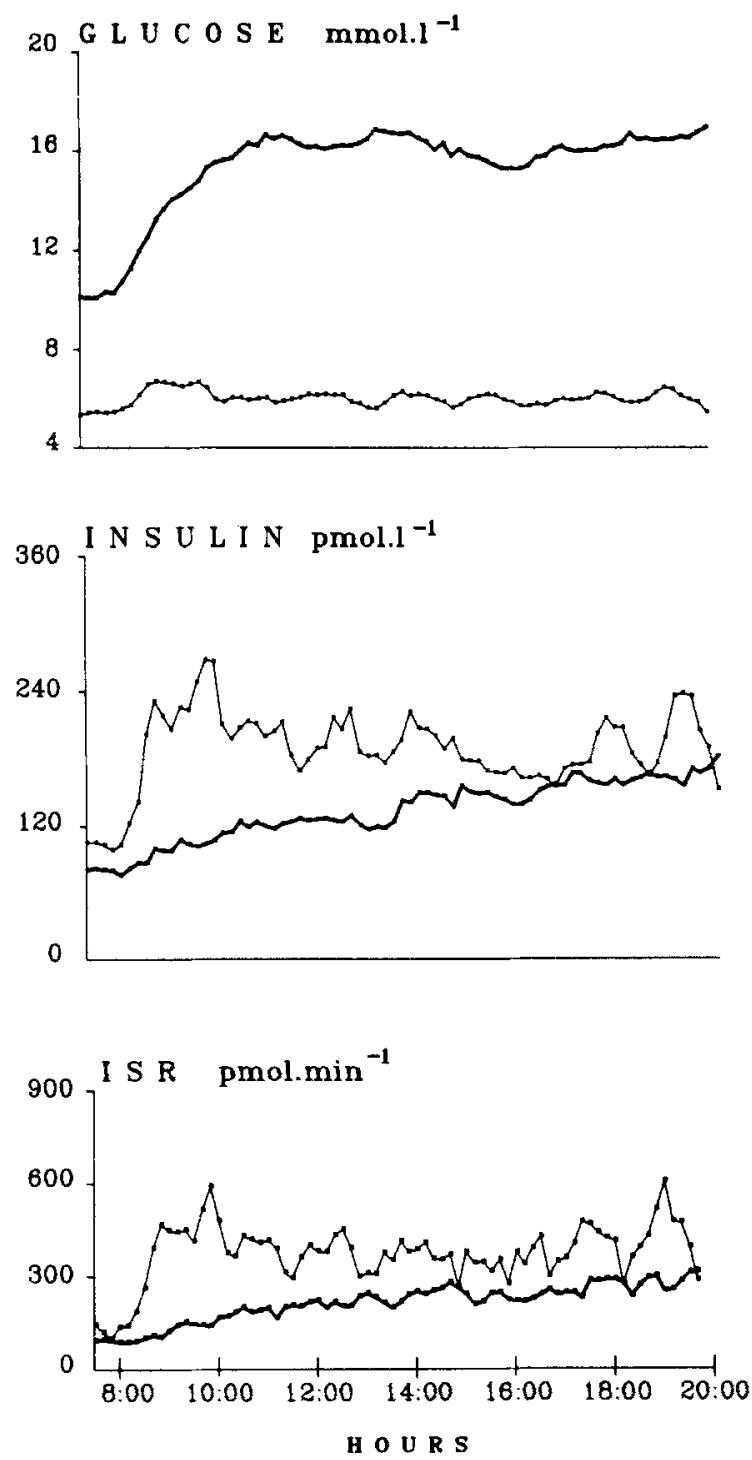

Fig. 1. Mean glucose, insulin and insulin secretion rate (ISR) profiles in the control subjects and the diabetic patients during continuous enteral nutrition. $\rightarrow=$ control subjects, $-=$ diabetic subjects 
Table 2. Initial and mean glucose, insulin and insulin secretion rate (ISR) levels in control subjects and in Type 2 (non-insulin-dependent) diabetic patients under continuous enteral nutrition

\begin{tabular}{lcc}
\hline & Initial levels & Mean levels \\
\hline Glucose, mmol $/$ & & \\
$\quad$ Control subjects & $5.38 \pm 0.28$ & $6.05 \pm 0.17$ \\
Diabetic patients & $10.32 \pm 1.50$ & $16.15 \pm 1.78$ \\
$p$ value & 0.05 & 0.05 \\
Insulin, pmol $/ 1$ & & \\
Control subjects & $105.40 \pm 12.91$ & $187.85 \pm 29.39$ \\
$\begin{array}{l}\text { Diabetic patients } \\
p \text { value }\end{array}$ & $86.76 \pm 13.62$ & $135.51 \pm 15.06$ \\
Insulin secretion rate pmol/min & $\mathrm{NS}$ & $\mathrm{NS}$ \\
$\begin{array}{l}\text { Control subjects } \\
\text { Diabetic patients } \\
p \text { value }\end{array}$ & $130.12 \pm 43.35$ & $356.56 \pm 53.14$ \\
& $76.07 \pm 27.83$ & $194.82 \pm 44.94$ \\
& $\mathrm{NS}$ & 0.05 \\
\hline
\end{tabular}

Table 3. Analysis of the first oscillation

\begin{tabular}{|c|c|c|c|c|c|}
\hline & $\begin{array}{l}\text { Latency } \\
\text { (min) }\end{array}$ & $\begin{array}{l}\text { Absolute } \\
\text { amplitude }\end{array}$ & $\begin{array}{l}\text { Relative } \\
\text { amplitude } \\
(\%)\end{array}$ & $\begin{array}{l}\text { Dura- } \\
\text { tion } \\
\text { (min) }\end{array}$ & $\begin{array}{l}\text { Duration } \\
\text { of the as- } \\
\text { cending } \\
\text { phases } \\
\text { (min) }\end{array}$ \\
\hline \multicolumn{6}{|l|}{ Glucose, $\mathrm{mmol} / \mathrm{l}$} \\
\hline $\begin{array}{l}\text { Control subjects } \\
\text { Diabetic patients } \\
p \text { value }\end{array}$ & $\begin{array}{c}76 \pm 8 \\
132 \pm 18 \\
\text { NS }\end{array}$ & $\begin{array}{c}1.83 \pm 0.22 \\
6.33 \pm 0.77 \\
0.05\end{array}$ & $\begin{array}{c}30 \pm 3 \\
40 \pm 5 \\
\text { NS }\end{array}$ & $\begin{array}{c}108 \pm 12 \\
150 \pm 20 \\
\text { NS }\end{array}$ & $\begin{array}{c}80 \pm 12 \\
127 \pm 17 \\
\text { NS }\end{array}$ \\
\hline \multicolumn{6}{|l|}{ Insulin, pmol/l } \\
\hline $\begin{array}{l}\text { Control subjects } \\
\text { Diabetic patients } \\
p \text { value }\end{array}$ & $\begin{array}{c}80 \pm 12 \\
102 \pm 20 \\
\text { NS }\end{array}$ & $\begin{array}{c}196.46 \pm 51.62 \\
56.64 \pm 12.91 \\
0.05\end{array}$ & $\begin{array}{c}98 \pm 17 \\
41 \pm 7 \\
0.05\end{array}$ & $\begin{array}{c}112 \pm 17 \\
88 \pm 20 \\
\text { NS }\end{array}$ & $\begin{array}{c}62 \pm 12 \\
65 \pm 19 \\
\text { NS }\end{array}$ \\
\hline \multicolumn{6}{|c|}{ Insulin secretion rate, $\mathrm{pmol} / \mathrm{min}$} \\
\hline $\begin{array}{l}\text { Control subjects } \\
\text { Diabetic patients } \\
p \text { value }\end{array}$ & $\begin{array}{c}82 \pm 13 \\
110 \pm 56 \\
\text { NS }\end{array}$ & $\begin{array}{c}550 \pm 89 \\
92 \pm 14 \\
0.05\end{array}$ & $\begin{array}{c}157 \pm 19 \\
59 \pm 14 \\
0.05\end{array}$ & $\begin{array}{c}93 \pm 10 \\
127 \pm 62 \\
\text { NS }\end{array}$ & $\begin{array}{c}70 \pm 9.9 \\
102 \pm 55 \\
\text { NS }\end{array}$ \\
\hline
\end{tabular}

Table 4. Analysis of the oscillatory pattern (without the first oscillation)

\begin{tabular}{|c|c|c|c|c|c|}
\hline & $\begin{array}{l}\mathrm{N}^{\circ} \text { of signifi- } \\
\text { cant pulses/h }\end{array}$ & $\begin{array}{l}\text { Absolute } \\
\text { amplitude }\end{array}$ & $\begin{array}{l}\text { Rela- } \\
\text { tive am- } \\
\text { plitude } \\
\%\end{array}$ & $\begin{array}{l}\text { Dura- } \\
\text { tion } \\
\text { (min) }\end{array}$ & $\begin{array}{l}\text { Dura- } \\
\text { tion of } \\
\text { the as- } \\
\text { cending } \\
\text { phases } \\
\text { (min) }\end{array}$ \\
\hline \multicolumn{6}{|l|}{ Glucose, $\mathrm{mmol} / 1$} \\
\hline $\begin{array}{l}\text { Control subjects } \\
\text { Diabetic patients } \\
p \text { value }\end{array}$ & $\begin{array}{c}0.78 \pm 0.06 \\
0.66 \pm 0.09 \\
\mathrm{NS}\end{array}$ & $\begin{array}{c}0.94 \pm 0.17 \\
1.72 \pm 0.22 \\
0.05\end{array}$ & $\begin{array}{r}15 \pm 3 \\
10 \pm 1 \\
\text { NS }\end{array}$ & $\begin{array}{c}72 \pm 5 \\
75 \pm 8 \\
\text { NS }\end{array}$ & $\begin{array}{r}31 \pm 3 \\
35 \pm 9 \\
\text { NS }\end{array}$ \\
\hline \multicolumn{6}{|l|}{ Insulin, pmol/l } \\
\hline $\begin{array}{l}\text { Control subjects } \\
\text { Diabetic patients } \\
p \text { value }\end{array}$ & $\begin{array}{c}0.75 \pm 0.06 \\
0.40 \pm 0.08 \\
0.01\end{array}$ & $\begin{array}{c}96.80 \pm 27.25 \\
43.02 \pm 4.30 \\
0.05\end{array}$ & $\begin{array}{c}49 \pm 7 \\
32 \pm 3 \\
\text { NS }\end{array}$ & $\begin{array}{c}70 \pm 7 \\
123 \pm 27 \\
\text { NS }\end{array}$ & $\begin{array}{l}30 \pm 3 \\
67 \pm 12 \\
0.05\end{array}$ \\
\hline \multicolumn{6}{|c|}{ Insulin secretion rate, $\mathrm{pmol} / \mathrm{min}$} \\
\hline $\begin{array}{l}\text { Control subjects } \\
\text { Diabetic patients } \\
p \text { value }\end{array}$ & $\begin{array}{c}1.03 \pm 0.08 \\
0.43 \pm 0.11 \\
0.01\end{array}$ & $\begin{array}{l}330 \pm 53 \\
162 \pm 30 \\
0.05\end{array}$ & $\begin{array}{l}94 \pm 9 \\
88 \pm 10 \\
\text { NS }\end{array}$ & $\begin{array}{c}64 \pm 5 \\
123 \pm 22 \\
0.05\end{array}$ & $\begin{array}{l}32 \pm 4 \\
74 \pm 17 \\
0.05\end{array}$ \\
\hline
\end{tabular}

ma glucose levels were significantly higher in the diabetic patients compared with the control subjects $(p<0.05)$ (Table 2). In contrast, initial plasma insulin and ISR levels were similar in the two groups.

For the control subjects, the mean plasma glucose levels increased 30 min after continuous enteral nutrition was started, reaching a peak level of $6.77 \pm 0.44 \mathrm{mmol} / \mathrm{l}$ after $70 \mathrm{~min}$. Plasma glucose levels close to a value of $6 \mathrm{mmol} / \mathrm{l}$ were then maintained throughout the study. In the diabetic patients, the peak in plasma glucose which was higher $(17.70 \pm 1.78 \mathrm{mmol} / \mathrm{l} ; p<0.05)$ than for the control subjects was only attained after a period of $210 \mathrm{~min}$. As in the control subjects, it was followed by a steady-state, but at a higher level of about $16 \mathrm{mmol} / 1$; the mean glucose levels observed throughout the study were significantly higher in the diabetic patients than in the control subjects $(p<0.05)$.

In the control subjects, mean plasma insulin and ISR profiles were very similar to the mean plasma glucose profiles. After an initial peak which was attained $60 \mathrm{~min}$ after initiation of the enteral infusion, the mean levels appeared constant throughout the study. In contrast the mean plasma insulin and ISR profiles of the diabetic patients showed a slow ascending trend without displaying an initial peak. Contrasting with the higher mean levels of glucose, mean plasma insulin as well as those of ISR were lower in the diabetic patients, although this did not reach statistical significance for insulin (Table 2).

\section{Pulse analysis of the individual profiles}

Since the first pulse corresponded to the initiation of the enteral nutrition, it was analysed separately (Table 3 ). The characteristics of the subsequent pulses were calculated without taking the initial peak into account (Table 4),

First oscillation. The first oscillation of glucose had a higher amplitude in the diabetic patients than in the control subjects $(6.33 \pm 0.77$ vs $1.83 \pm 0.22 \mathrm{mmol} / \mathrm{l} ; p<0.05)$, contrasting with the lower absolute and relative amplitude of the first insulin and ISR pulses $(p<0.05)$. The mean duration of the first glucose and ISR pulses and the mean latency (defined as the time from initiation of enteral nutrition until the peak of the first pulse) were higher in the diabetic patients than in the control subjects giving a different visual aspect to the individual profiles, but these differences did not reach statistical significance.

Oscillatory pattern. As expected, analysis of the individual profiles revealed the existence, in the control subjects, of significant pulses of glucose, insulin, and ISR occurring throughout the experimental day, despite the constant rate of nutrient infusion. An individual example is illustrated in Figure 2. The pulses of glucose (mean $0.78 \pm 0.06 / \mathrm{h}$ ) which occurred with a mean interval of $88 \mathrm{~min}$ had a mean duration of $72 \pm 5 \mathrm{~min}$. They had an absolute amplitude of $0.94 \pm 0.17 \mathrm{mmol} / \mathrm{l}$ and a relative amplitude, expressed as a percentage of the $12 \mathrm{~h}$ mean of $15.3 \pm 3.0 \%$.

In the diabetic patients (Fig. 3) plasma glucose levels had an oscillatory pattern similar to that observed in the control subjects, with $0.66 \pm 0.09$ pulses/h being superimposed on the progressive ascending trend. Their mean duration was $75 \pm 8 \mathrm{~min}$. Their absolute amplitude was greater than for the control subjects $(1.72 \pm 0.22$ vs $0.94 \pm 0.17 \mathrm{mmol} / 1 ; p<0.05$ ), but their relative amplitude was not significantly different. 

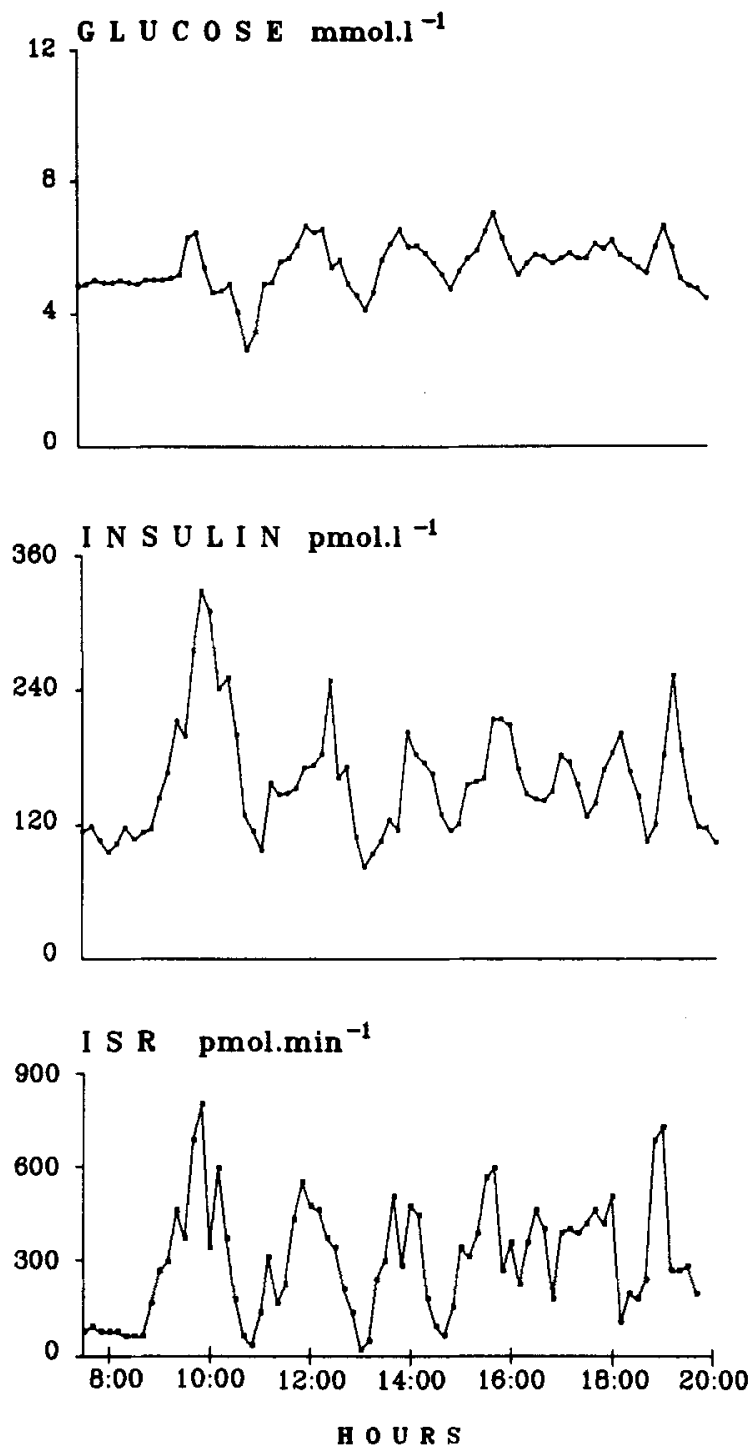

Fig.2. Individual glucose, insulin and insulin secretion rate (ISR) profiles in one control subject during continuous enteral nutrition

In contrast, the individual insulin and ISR profiles were quite different in the diabetic patients and in the control subjects. Whereas regular insulin and ISR pulses, with a mean duration similar to those of glucose were observed in the control subjects, the mean number of insulin and ISR pulses was significantly lower in the diabetic patients $(p<0.01)$. Despite the greater amplitude of the glucose pulses in the diabetic patients, the insulin and ISR pulses had a lower amplitude $(p<0.05)$ and were characterized by a longer ascending phase $(p<0.05)$. Total duration of the ISR pulses was greater in the diabetic patients $(p<0.05)$.

In the control subjects, a high degree of synchrony of the oscillations was apparent in that respectively $91 \%$ and $96 \%$ of the glucose oscillations occurred simultaneously with those of insulin and ISR (Table 5). $96 \%$ of the total insulin pulses and $85 \%$ of the ISR pulses were associated with a glucose pulse. In the diabetic patients, the insulin and ISR pulses which were less regular, were poorly associated with those of glucose. On average $43 \%$ and $39 \%$ of the glucose oscillations occurred concomitantly with respect to insulin and ISR pulses. Moreover, in some of the patients, glucose oscillations were present in the absence of any concomitant insulin and ISR pulses (Fig. 3). Only $56 \%$ and $48 \%$ of the total number of insulin and ISR pulses were associated with glucose pulses which significantly differed from the control subjects $(p<0.05)$.

\section{Discussion}

The existence, in normal subjects, of slow oscillations of peripheral glucose, insulin and C-peptide is well documented and has been found after administration of enteral or parenteral nutrition [5-8]. Recently the kinetics of C-peptide have been found to be similar in normal and diabetic subjects [13], so that the pancreatic insulin secretion rate can be accurately derived from peripheral Cpeptide levels using an open two-compartment mathematical model [16]. Using this approach, allowed by the high sampling frequency, we found that in normal man the oscillations of glucose observed during a constant enteral infusion are associated with significant pulses of insulin secretion, which had a similar periodicity and duration but a higher amplitude. The pulses of glucose and insulin secretion were closely related with more than $90 \%$ of concomitancy confirming their probable interdependence. These results are similar to those found during constant glucose infusion in man [8] and in dog [17], although the mean time of period of insulin and ISR pulses was slightly shorter in our study.

In the diabetic patients, mean plasma insulin and ISR were lower than in the control subjects, contrasting with the higher plasma glucose levels and confirming that insulin secretion is reduced in Type 2 diabetes [18]. The oscillatory pattern of peripheral glucose levels was very similar to that observed in the control subjects, despite the quite different pattern of insulin secretion rate. In the control subjects insulin secretion rapidly increased and subsequently showed a regular oscillatory pattern, whereas in the diabetic patients the increment of insulin secretion was very slow throughout the $12 \mathrm{~h}$ experiment. Insulin secretory pulses were generally superimposed on this slow trend but the pulses were less frequent, less regular and of smaller amplitude than those observed in the control subjects; they were poorly associated with the glucose pulses and in some of the patients an absence of any pulse of insulin secretion was observed despite the regular oscillatory pattern of glucose. The apparent difference in the pulse frequency of insulin secretion in the diabetic and the control subjects could, in part, be explained by analytical limitations. However, the initial insulin levels were in the same range for the two groups, excluding false negatives due to a lower sensitivity of the RIA at different levels. The calculation of the rate of instantaneous prehepatic insulin secretion from peripheral C-peptide concentrations permitted the elimination of possible artifacts in relation to the large and variable hepatic extraction of insulin, which could have smoothed the insulin profiles; however, one cannot exclude the presence of very small prehepatic secretory pulses. If this was the case, Type 2 

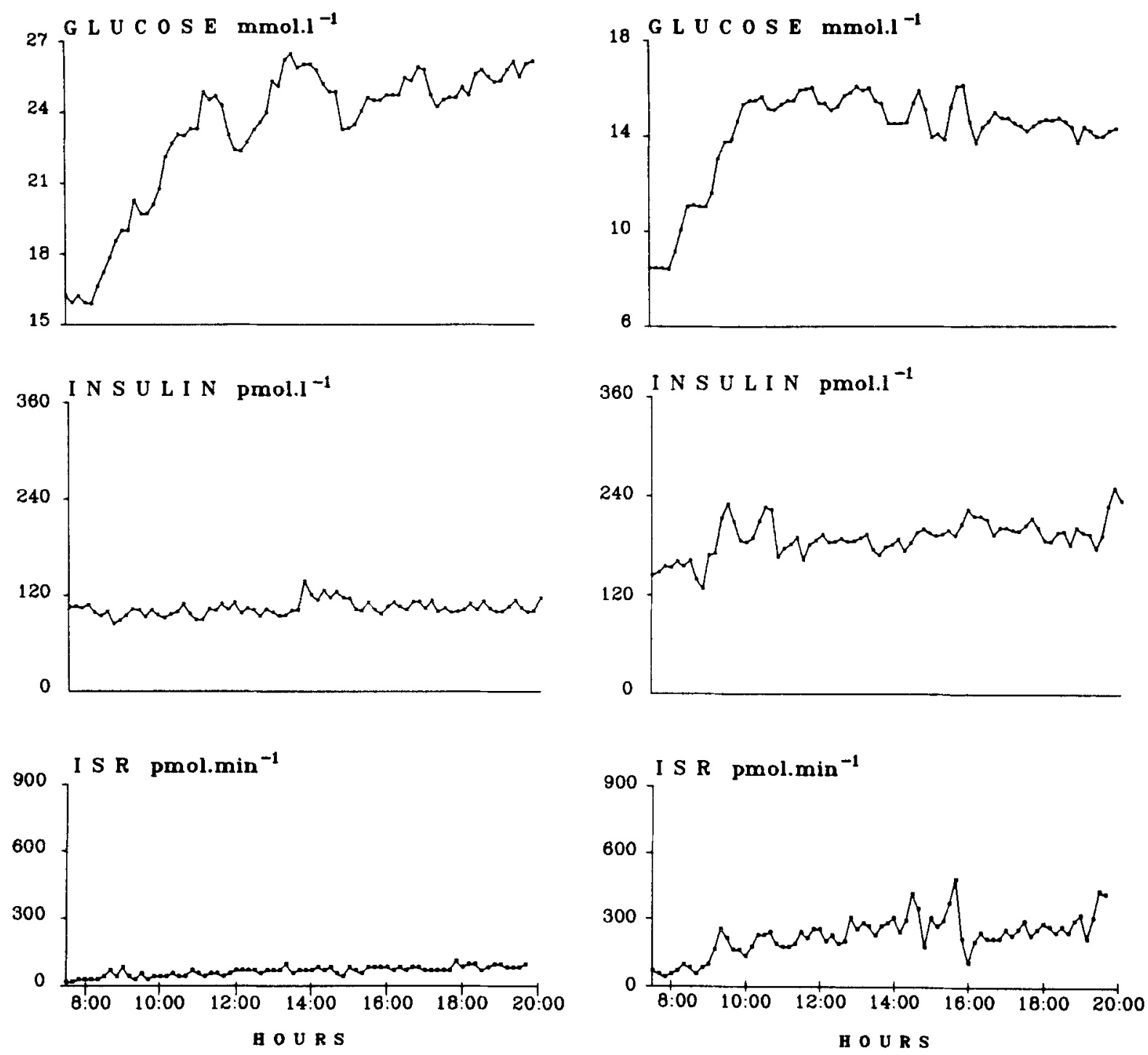

Fig.3. Individual glucose, insulin and insulin secretion rate (ISR) profiles in two Type 2 (non-insulin-dependent) diabetic patients during continuous enteral nutrition

diabetes could be associated with a decrease in the amplitude of the pulses, which would be more marked in some of the patients but without any other anomaly. The lower frequency of the ISR pulses and their weaker association with the glucose pulses in our patients could also reflect a disruption of the temporal coordination of the pancreatic islet activity. A similar disruption of the post-meal insulin secretion pattern, which is normally characterized by a series of damped oscillations has recently been reported in diabetic patients, during a $24 \mathrm{~h}$ study with three meals [9]. An abnormal oscillatory pattern has also been described in diabetic patients for the rapid 8-15 min insulin oscillations $[19,20]$.

The mechanism underlying glucose pulses is not clearly known and more than one mechanism could be involved. An intrinsic property of the glucose-insulin regulatory loop would explain the damped oscillations after meal ingestion $[5,6]$ and the pulses observed during constant glucose infusion [8] which are very similar to those reported here during continuous enteral nutrition in the control subjects. However, such a mechanism could not be responsible for the glucose pulses which were observed in some of the diabetic patients, in the absence of any concomitant insulin or ISR pulse. Moreover, the prehepatic ISR pulses present in the patients are probably too small to account for the high glucose pulses. The occurrence of pulses of glucose and insulin secretion during the immediate post-meal period, with a concomitancy similar to that observed in our study $[5,6]$ contrasted with the lower concordance (about $50 \%$ ) of the glucose and ISR pulses observed at distance of the meal when nutrient stimulation is no longer present $[6,9]$. Although this fact may be ex-

Table 5. Concomitancy of the pulses

\begin{tabular}{lll}
\hline$\%$ glucose pulses associated with & Insulin & Insulin secretion rate \\
Control subjects & $91 \%$ & $96 \%$ \\
Diabetic patients & $43 \%$ & $39 \%$ \\
$p$ value & 0.05 & 0.05 \\
\% of the total number of pulses & & \\
associated with glucose & Insulin & Insulin secretion rate \\
Control subjects & $96 \%$ & $85 \%$ \\
Diabetic patients & $56 \%$ & $48 \%$ \\
$p$ value & 0.05 & 0.05 \\
\hline
\end{tabular}


plained by the detection limit of small secretory episodes, it could also favour the hypothesis that the stimulation of glucose by factors which depend on food ingestion plays an important part in the synchronization between the glucose and insulin secretion pulses. Such a mechanism mediated by the gastrointestinal tract would explain the occurrence of glucose pulses in the absence of any insulin pulse. However, it would not exclude the potential role of the glucose-insulin regulatory loop in the control subjects. Alternatively a common oscillatory factor could influence both the glucose and the insulin secretion pulses.

In summary, this study revealed profound differences in the insulin secretory pattern between Type 2 diabetic patients and normal male subjects. Such an abnormal pattern may be implicated as an important factor in the pathogenesis of Type 2 diabetes as it has been suggested for the pulses of shorter periodicity [21]. Whatever the physiological role of intermittent insulin release, the poor concomitance of insulin and glucose pulses in the diabetic patients raises the question of the mechanism generating the oscillatory glucose pattern.

Acknowledgements. We thank B. Reinhardt and M. Simeoni for experimental assistance and RIA analysis. We are indebted to Dr. J.M.Kahn and Sandoz Nutrition, Bern, Switzerland, for financial support.

\section{References}

1. Goodner CJ, Walike BC, Koerker DJ, Ensinck JW, Brown A, Chideck EW, Palmer J, Kalnasy L (1977) Insulin, glucagon, and glucose exhibit synchronous, sustained oscillations in fasting monkeys. Science 195: 177-179

2. Lang DA, Matthews DR, Peto J, Turner RC (1979) Cyclic oscillations of basal plasma glucose and insulin concentrations in human beings. N Engl J Med 301: 1023-1027

3. Hansen BC, Jen KC, Pek SB, Wolfe RA (1982) Rapid oscillations in plasma insulin, glucagon, and glucose in obese and normal weight humans. J Clin Endocrinol Metab 54: 785-792

4. Stagner JL, Samols E, Weir GC (1980) Sustained oscillations of insulin, glucose and somatostatin from the isolated canine pancreas during exposure to a constant glucose concentration. J Clin Invest 65: 939-942

5. Simon C, Follenius M, Brandenberger G (1987) Postprandial oscillations of plasma glucose, insulin and C-peptide in man. Diabetologia 30: 769-773

6. Polonsky KS, Given BD, Van Cauter E (1987) Twenty-four-hour profiles and pulsatile patterns of insulin secretion in normal and obese subjects. J Clin Invest $81: 442-448$

7. Simon C, Brandenberger G, Follenius M (1987) Ultradian oscillations of plasma glucose, insulin, and C-peptide in man during continuous enteral nutrition. J Clin Endocrinol Metab 64: 669674
8. Shapiro ET, Tillil H, Polonsky KS, Fang VS, Rubenstein AH, Van Cauter E (1988) Oscillations in insulin secretion during constant glucose infusion in normal man: relationship to changes in plasma glucose. J Clin Endocrinol Metab 67: 307-314

9. Polonsky KS, Given BD, Hirsh LJ, Tillil H, Shapiro ET, Beebe C, Frank BH, Galloway JA, Van Cauter E (1988) Abnormal patterns of insulin secretion in non-insulin-dependent diabetes mellitus. N Engl J Med 318: 1231-1239

10. Hales CN, Randle PJ (1963) Immunoassay of insulin using a twoantibody precipitate. Biochem J 88: 137-146

11. Eaton RP, Allen RC, Schade DS, Erickson KM, Standefer J (1980) Prehepatic insulin production in man: kinetic analysis using peripheral connecting peptide behavior. J Clin Endocrinol Metab 51: $520-528$

12. Polonsky KS, Licinio-Paixao J, Given BD, Pugh W, Rue P, Galloway J, Karrison T, Frank B (1986) Use of biosynthetic human Cpeptide in the measurements of insulin secretion rates in normal volunteers and Type I diabetic patients. J Clin Invest 77: 98-105

13. Shapiro ET, Van Cauter E, Tillil H, Given BD, Hirsch L, Beebe C, Rubenstein AH, Polonsky KS (1989) Glyburide enhances the responsiveness of the $\beta$-cell to glucose but does not correct the abnormal patterns of insulin secretion in noninsulin-dependent diabetes mellitus. J Clin Endocrinol Metab 69:571-576

14. Van Cauter E (1981) Quantitative methods for the analysis of circadian and episodic hormone fluctuations. In: Van Cauter E, Copinschi G (eds) Human pituitary hormones: circadian and episodic variations. Martinus Nijhoff, The Hague, pp 1-25

15. Van Cauter E (1988) Estimating false-positive and false-negative errors in analysis of hormonal pulsatility. Am J Physiol (Endocrinol Metab 17) 254: E786-E794

16. Polonsky KS, Frank B, Pugh W, Addis A, Karrison T, Meier P, Tager H, Rubenstein AH (1986) The limitations and valid use of C-peptide as a marker of the secretion of insulin. Diabetes 35: 370-386

17. Ookhtens M, Marsh DJ, Smith SW, Bergman RN, Yates FE (1974) Fluctuations of plasma glucose and insulin in conscious dogs receiving glucose infusions. Am J Physiol 238: E395-E341

18. Cahill GF (1988) Beta-cell deficiency, insulin resistance, or both? N Engl J Med 319: 1268-1269

19. O'Rahilly S, Turner TC, Matthews DR (1988) Impaired pulsatile secretion of insulin in relatives of patients with non-insulin dependent diabetes. N Engl J Med 318:345-349

20. Lang DA, Matthews DR, Burnett M, Turner RC (1981) Brief,irregular oscillations of basal plasma insulin and glucose concentration in diabetic man. Diabetes 30: 435-439

21. Husain M (1988) Pulsatile secretion of insulin. N Engl J Med 30: 1094-1095

Received: 22 October 1990

and in revised form: 25 February 1991

Dr. C. Simon

Laboratoire de Physiologie

et de Psychologie Environnementales

CNRS/INRS

21 rue Becquerel

F-67087 Strasbourg Cedex

France 